\title{
Peace operations in Southern Africa: Challenges and prospects for the Southern African Development Community Standby Force
}

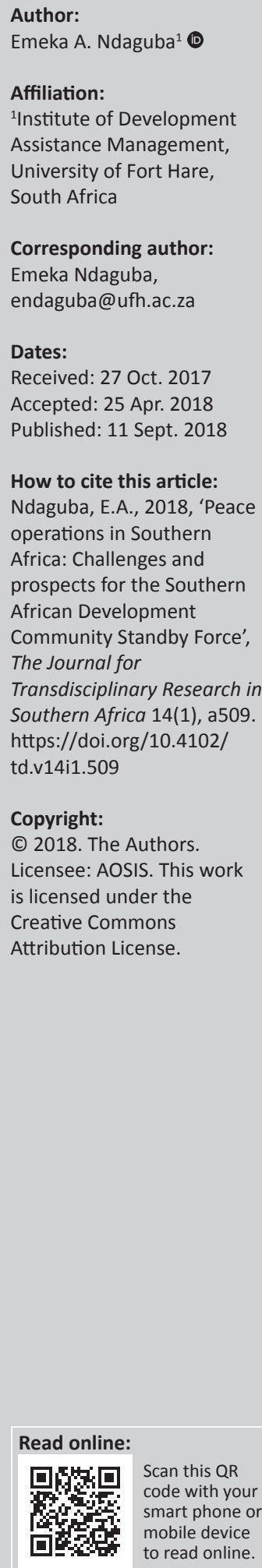

\begin{abstract}
The viability and operability of the Southern African Development Community Standby Force (SADCSF) is threatened by two principal factors: overdependence on foreign peacekeeping operations and inability of the SADCSF to fund its operations. The objective of this article is to explore the challenges and prospects that create a conducive environment in which the SADCSF in Southern Africa is able to intervene in peace operations and become financially viable. The methodology for gathering and analysing data for this study was based on secondary data sources, namely narrative analysis, systematic quantitative literature review, social constructivism and interpretivist approach, triangulation and thematic analysis. The findings of the article revealed that the SADCSF does not have a financial model for funding peace operations in the region. It also demonstrated financial inadequacies have consequently led to the inability of the Force to intervene in peace missions in Southern Africa. From the foregoing, it is evident that much still needs to be achieved for the SADCSF to possibly be operational, thus the identification of several indicators. The analyses from the article portray that, while much has been achieved, much more is yet to be realised in terms of fiscal viability, sustainability, responsibility and integration. It is recommended that an adequate monitoring group be established. It is also recommended that a planning commission be established for the SADCSF and that an adequate funding method be built based on each individual country's ability to pay. Finally, a separate budget for funding peace operation should be established.
\end{abstract}

\section{Introduction}

According to Kotia (nd:6), on a global scale there are six main elements of defence security in relation to social sciences, namely military security (implying the capability of a nation to defend itself and deter military aggression); political security (concerning the stability of the social order and specifically addressing threats to sovereignty); economic security (freedom to follow choice of policies to develop a nation's economy in the manner desired; forms the essence of economic security); environmental security (dealing with environmental issues that threaten the national security of a nation in any manner); security of energy and natural resources (including water, sources of energy, land, oil and minerals) and most recently human security (such as poverty, social grants and welfare) (Kotia nd:6). While all six are paramount, military security is an essential guarantee for the realisation of the other security elements. This is because several studies have linked peace and stability within a country to economic development; human development; the protection of energy and natural resources; political stability; and environmental protection (Chellah 2014:4; Gaddis 1982; Homan 2006; NATO Handbook 2001:203; Ndaguba 2016; Weihrich 1982:2-4).

Based on the aforementioned, an effective, viable, sustainable and functional standby force like the Southern African Development Community Standby Force (SADCSF) is of utmost concern and need. However, the activities and functionality of the SADCSF are curtailed by an overdependence on foreign peacekeeping operations in the region, by independent member states (see South African Defence Force) and chiefly by non-existent funding models for generating funds for the SADCSF. Premised on the incidence that hampers the efficiency of the SADCSF, as described, this article explores the challenge that plagues the operability of the SADCSF and the opportunities thereof for funding the force - principally, because as Allison, Jackson and Ndaguba et al. noted, 'funding is key, funding is everything ... it determines capability, movement, equipment and maintenance, payments to injured soldiers. If we can sort that out, the rest can 
follow' (Allison 2013; Jackson 2013; Ndaguba, Nzewi \& Shai 2018). Without an adequate funding mechanism for the SADCSF, planning, organising, staffing, training, and coordination would seem difficult, if not impossible (Ndaguba 2018). This is probably the reason why the components saddled with the functionality of the SADCSF programmes are yet functional in full capacity. It is therefore important to see theories that support regional security, taking into account elements that make up functional and adequate regional security architecture. This article must be understood as one in a series of articles that deals breaks down the philosophy of a research study on Financing Regional Peace and Security in Africa: A Critical Analysis of the Southern African Development Community Standby Force this particular article deals with the prospect and challenges for funding peace operations.

\section{Strategy theory}

There are several theories in international relations and world politics that give credence to the formation and formalisation of regional security forces globally. However, the posture of this article (and series of articles) is shaped towards the proposition of a funding model for regional security on the African continent and how these financial burdens on member states can be reduced. This article examines strategy theory in international relations and security studies and their opportunities in creating an understanding for the establishment and operability of a regional defence force.

Strategy theory is situated in the interdisciplinary academic field of strategic studies and strategic management (Furrer, Thomas \& Goussevskaia 2008:6). It is concerned with the study of peace, conflict strategies and strategic development of organisations (Ndaguba 2016), more often than not devoting attention to the relationship between international diplomacy, geostrategy, military power, international economics, international administration and politics (Gaddis 1982). The theory is useful in providing an understanding of the role of diplomacy, intelligence and international cooperation for regional security and defence operations (Weihrich 1982:2-4), with a particular interest in the way a (defence) organisation can best function adequately.

However, there are several uses or misapplications of the concept of strategy. For instance, in the field of strategic management and strategic planning, authors such as Richard Vancil, Kenneth Andrews, George Sterner, Alfred Chandler and John Miner focus on the part of the story dealing with the achievement of ends (Chandler 1962; 2013; Learned et al. 1965; Lorange \& Vancil 1977; Steiner \& Miner 1977), while authors such as Igor Ansoff, Dan Schendel and Charles Hofer place emphasis on the means through which the end is realised (Ansoff 1965; Hofer \& Schendel 1978). With some placing a higher emphasis on the final goal of the strategy, others have placed emphasis on the way and manner the ends is realised. In this article, both the ends and the means are critical because most ends undermine the humanness in conflict situations (see the Biafra War 1967-1970).

Strategy theory is essential in decision-making (Yarger 2006; 2008). Hence, it hinges on the argument that wellcrafted strategies are road maps that guide policymakers in making decisions that add value to society (ToddZenger 2015). Essentially the function of strategy theory is to ensure the advancement, pursuit and protection of interests. Yarger $(2006 ; 2008)$ stipulated that 15 assumptions be encapsulated in the strategy theory, which is in tandem with the arguments of Trager and Simonie (1973:36) and Rosecrance and Stein (1993:4), who argue that the strategic process is concerned with how leaders use the power available to the state to exercise control over situations to achieve objectives. In relation to strategy being about protection of interest, Jordan et al. (2009), Milward (1979:21) and Burrowes (1996:29) argue that strategies are governed by political interest and purpose. More importantly, the design of any strategy is based on two factors, namely territorial and environmental, because every strategy is designed based on the understanding of the geography or landscape of the environment. Yarger (2008:150) argues that while considering the physical and metaphysical attributes of the environment should be a priority in the conceptualisation and design of the strategic method, strategic processes must be holistic and inclusive in nature. In separate studies, Yarger articulates that the emphasis of every strategy must be an inclusive approach (Yarger 2006:8). To Jervis, another important factor of the strategic process is loyalty (Jervis 1997:60). National interests sometime compromise the global agenda; consequently, the interests and values of actors sometimes constitute a dilemma in formulating a strategy for a given area (Eising 2005:223-224).

However, there are several reasons for the formulation of a strategy, including strategy is to focus on finding the root causes and purposes of a conflict or problem (Cimbala 2001; Steiss 2003:171). Some strategies have symbiotic relationship with time (Jermy 2011). Strategy is cumulative in the sense that properties in strategic environments are increasing from several different perspectives. Strategy balances the relationship between objectives, methods and resources for achieving the goals of an operation in a hierarchical manner. Every strategy intends to harmonise the ends, the means and the methods of achieving a goal (Yarger 2006; 2008).

The functions espoused by Yarger and others can only be meaningful where the strategist takes cognisance of the following three constraints to successful implementation of strategies on a global scale:

Holistic: An all-inclusive approach to a situation must be taken into cognisance of a situation before intervention or the clearance for intervention is issued, such clearance to the finances; environment; timeline; communication pattern and stream; political, social and cultural dynamics; personnel; equipment; treatment facilities as well as the interactions and linkages connecting each strategic activity to the other must 
be established before the Force is deployed (Gane 2007:256). The entire strategy must be seen as one, with different parts that function effectively in maintaining the momentum of the central strategy from the onset.

Sustainable: This deals with the capacity of a sector to provide current and future outputs that ensure the proper flow or deployment of finances, personnel and equipment (Gane 2007).

Equitable: Equity is key in life as it is to strategy. It speaks to justice and social order. Without equity no strategic activity can be accomplished, in that every strategy is premised on the central idea of a collective effort. Equity reduces doubts, seizes fears and repels discrimination, which are products of confusion. For any strategy to succeed, cost must be distributed based on what was agreed at the initial stage through a fair accord; otherwise the essence of a strategy would be compromised (Gane 2007). Thus, every achievable strategy in military studies demands the collective effort of military professionalism in formulating, articulating, evaluating or executing the strategy (Yarger 2006:ix).

\section{Research methodology}

There is no one best way or method in social research for conducting research, either qualitative or quantitative (Ndaguba 2016:12). Every social research inquiry hinges on the ability of the researcher to gather reasonable data that support the topic under review. A synopsis of the mechanism for gathering and analysing data in this article can be found in Table 1.

The rock-bottom assumptions of desktop research are as follows:

- knowing where to look and what to look for;

- understanding the quality of the source material;

- ensuring you get the right information.

The desktop approach was favourable in this study, premised on the following:

- issues on security and financing security would not be easily accessible;

TABLE 1: Summary of proposed method.

\begin{tabular}{ll}
\hline Methodology & Activities \\
\hline The method adopted & $\begin{array}{l}\text { The article explores the research question by using } \\
\text { a qualitative paradigm (desktop method). }\end{array}$ \\
The research design & $\begin{array}{l}\text { The article hinges on an exploratory research } \\
\text { study, which helps to give perspective to relatively } \\
\text { new issues. }\end{array}$ \\
The logic of the study & $\begin{array}{l}\text { The rationale is to validate and discover the } \\
\text { challenges dwarfing the intervention of the } \\
\text { SADCSF, as well as factors that have inhibited } \\
\text { operability or functionality of the SADCSF. }\end{array}$ \\
The approach & $\begin{array}{l}\text { The approach adopted in this article is the case } \\
\text { study approach, which tends to give a holistic or } \\
\text { critical view about a phenomenon. }\end{array}$ \\
Data collection method & $\begin{array}{l}\text { Data were collected using the secondary method } \\
\text { of data collection. }\end{array}$ \\
Data analysis & $\begin{array}{l}\text { Data were analysed using thematic analysis, } \\
\text { systematic literature review and context analysis. }\end{array}$ \\
\hline
\end{tabular}

SADCSF, Southern African Development Community Standing Force.
- the possibility of gathering official financial statements owing to the non-existence of an administrative building or support staff; and

- the secrecy in security.

\section{Data collection based on secondary data}

Secondary data analysis is the practice of probing or scrutinising data that have already been collected by someone else, often for a distinctly different purpose (Ndaguba 2016). As a research method, it ensures brevity while saving time, money and unnecessary duplication of research actions (Crossman ND). An advantage of the secondary source of data collection is that it is used to gain insight about a phenomenon. Its biggest weakness is the inability to generalise findings from such study.

\section{Presentation of results}

This section discusses several challenges and prospects available for funding the SADCSF towards engendering peace in the region.

No matter how careful one is in research, the researcher will never cover all the aspects in a single study, as science is ever living. This study does not pretend to cover all ramifications of financing regional peace operations in Southern Africa, however, it gives the strong conviction that there is a need to do something more than merely standing by, as the SADCSF has been standing by since 2007. Firstly, the study is based on the Southern African narrative; hence it predominantly deals with the force saddled with quick response in the region. Furthermore, one may argue that this article gave much essence to challenges to its prospect of the SADCSF to be financially viable. This entirely depends on a philosopher's perception and perspective, in that we see things differently. More so, a qualitative methodology was used because of shortage of funds, access to study location and materials, and the unavailability of resources that should have strengthened the argument even further. More specifically, this article must be seen and understood as one in a series of articles and not a standalone article on Financing Regional Peace and Security in Africa: A Critical Analysis of the Southern African Development Community Standby Force.

There are several challenges ravaging Southern Africa, among which are poorly constituted regional integration and cooperation mechanisms, insolvent financial streams for the security force, weak political power in the world economy, the nature of its regionalism, weak institutional frameworks, weaker alignments of regional economic cooperation and so on.

The first and most important challenge is the political economy of the Southern African states: Political economy is a science that rests on the assumption that capital, value, commodity, land, wealth and labour constitute its basic elements (Jevons 1957:1). It envisions that the value of a 
commodity is dependent entirely on utility (Jevons 1957:1). Inasmuch as two parties freely agree to exchange things of value so that both benefit from the exchange, total wealth is increased. Therefore, exchange depends on the value, the interest and the rationality of such exchange on the one hand, and the tendency of increasing the general wealth of both parties on the other hand, the later leads to a favourable balance of payment. Without recourse to the assumption that a dominant party (or strong state) may exist, due to the interrelationship between both the strong and the weak state, the weaker party may become prey to the stronger. The notion and idea of the worldsystems economy is a better way of understanding the dominant nature of larger economies to weaker and smaller economies; the idea of the core and the periphery is a case in point. Hence, among the 14 member states of the SADC, only South Africa is likely to have its voice heard in the international market (though infinitesimal, of course).

At the centre of any meaningful engagement in military studies is finance. According to Allision (2012), cited by Ndaguba and Okonkwo (2017:146), 'finance is key, finance is everything, it determines production, capacity, skill set, payment, equipment and machinery covering every facet of a functional military agency'. The existence and the operability of any force are highly dependent on the force's ability to generate funds for the intervention. However, having no traceable or even feasible source of funds for the SADCSF constitutes a hitch in peace interventions in conflict areas in the region, resulting in the way both the political and economic structures of the region have been constituted.

It is important to note that the internal budget of most of the SADC member states is far from being fiscally viable, sustainable, or responsible (see Figure 1) in that most (if not all) member states run their country's financial budget on deficit, loans and aids. This creates burdens on the institutions and governments to make internal governance subject to external scrutiny (to the lender). This is the nucleus of political economists, for they concern themselves not only with the mechanics of economics but also with the ideology that supports the translation from decision making to policy implementation.

According to Figure 1, over $90 \%$ of member states are operating with a structured deficit. Therefore, it could be argued that the feasibility of sustainable funding for interventions of the SADCSF is low and the morale for such engagement is not existent. Furthermore, the notion or culture of running a structural deficit budget is not limited to member states but also affects the regional body (see Table 2).

The overall fiscal balance (including grants) is calculated as revenue minus total expenditure. The fiscal balance over the last 5 years has fluctuated widely in the different SADC member states. Almost half of the member states end this period with a greater fiscal deficit than in 2008 (SADC 2015a).

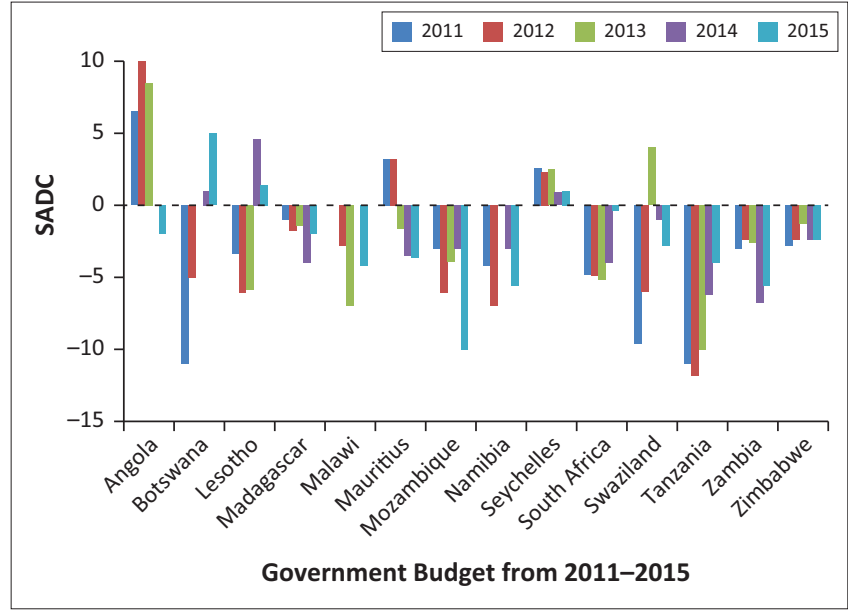

Source: Ndaguba and Okonkwo 2017:153

FIGURE 1: Southern African Development Community member states' internal budgets, 2011-2015.

TABLE 2: Southern African Development Community fiscal balance.

\begin{tabular}{lc}
\hline Year & \% GDP \\
\hline 2008 & 2.4 \\
2009 & -4.3 \\
2010 & -3.2 \\
2011 & -4.8 \\
2012 & -3.6 \\
\hline
\end{tabular}

Source: Ndaguba 2016

GDP, Gross domestic product

This picture is a result of the nature of regional and dependency syndrome, which has continually plagued the region and the continent as a whole.

Another important criteria is the nature of regionalism and regional activities in the region. There is a plethora of definitions for region, regionalism, regionalisation and regionness. Each of the definitions focuses on one or more dimensions, be it geographical proximity, economic unification, political economy, cultural identity or security interdependence (Buzan \& Wæver 2003; Cantori \& Spiegel 1970). All definitions provoke the study of regional alternatives either as regionness or regionhood (Hettne \& Söderbaum 2000). This article sees regionalism as statebased macro regions (three or more states), as opposed to micro regions, or territorial areas smaller than states. Geographic proximity has been argued as the basis for regionalism, as opposed to regionalisation. Regionalisation is often seen through the prism of regionness, which is principally for the purpose of trade but not exclusive to it. For example, the Organization of the Islamic Conference, Organization of Petroleum Exporting Countries, United Nations Conference on Trade and Development and the World Trade Organization all follow or have a common identity, ideology and sometimes culture (Fawcett \& Gandois 2010:619). Though both concepts are used loosely interchangeably, this article considers the concepts as separate yet interlinked. While the former (regionalisation) refers to a process that encompasses an increase in regionbased interaction and activity by state actors and non-state 
actors (non-state actors are usually the driving force such as individual, corporate organisations and non-governmental organisations), regionalism is simply a political project of state actors (Fawcett \& Gandois 2010:619).

The argument for regionalism is that it strengthens the whole (a collective action), in that collective action has greater effect than independent action (single action). As put simply by Van Langenhove (2005:5), regional integration is a 'process in which units move from a condition of total or partial isolation towards a complete or partial unification'. In this case, the unification towards strengthening regional security forces to combat the threat and avert violence in the Southern region of the African continent is necessary as the only means through which sustainable peace could be fast-tracked.

With an already established interconnection between peace, security and development in the late 1980s and 1990s, international laws and academics in international development and conflict resolution agree that the roles regional economic and security organisations play in conflict management, stabilisation, peacebuilding and non-violent mechanisms are critical in averting vehemence (violence) and ensuring integration in post-war situations in Africa (Francis 2002).

The challenges of securing Africa and ensuring development of its citizens can be traced to the division of the continent for administrative convenience by the West. This consequently resulting in a completely misconceived analogy (Gibb 2009:702), which Campion and Thayer (1987:78) refer to as 'arbitrary grouping of activities' and in this case 'an arbitrary demarcation of countries'. Though the essence of regionalism encompasses efforts by groups of nations to integrate and enhance their political, economic, cultural and social collaboration and to improve the living standard of the citizens through mutual interaction (Chingono \& Nakana 2009:396; Lee 2002:1). Such efforts can take on different forms, including regional cooperation, market integration, development integration and regional integration.

The African Union (AU) has continually argued that economic integration and cooperation is the engine to propel African development (Ginkel, Court \& van Langenhove 2003:1). This strengthens the idea of regionalism and regional integration as a major tool towards achieving growth and development on the continent, premised on mutual cooperation and agreement. However, the regions have not profited much from these assumptions of the regionalism and regional integration. This is a result of ideological difference, the political undertone of most issues in Africa, unwillingness, inability of some member states to take a decision for their countries because of Western influence or dominance, thereby stirring discrepancies in decision making among others (Allison 2015; Mataboge \& Pillay 2014).
The lack of cohesiveness is the lack of finances on a regional scale as a result of the proliferation of various security institutions, programmes and budgets, which has constantly led reviews of erstwhile programmes and financing mechanisms for the continent (Jentzsch 2014:2). Consequently, this proliferation of security institutions (African Standby Force, SADC-Organ on Politics, Defence and Security Cooperation, ECOMOG, African Capacity for Immediate Response to Crises, etc., to mention a few) has resulted in the shortage of funds, owing to five major blocs:

the inadequacy of $\mathrm{UN}$ reforms to overcome financing constraints; global financial meltdown; the insufficiency and unpredictability of voluntary contributions; restrain of contributor due to mixed track records of some peace operations; and the limited capacity of African regional organizations. (Jentzsch 2014; Ndaguba et al., 2018:13; Sabra 2011:1)

Moreover, studies have shown that some member states of SADCSF are also members of other regional economic communities (RECs) (Cilliers 2008:2). Double loyalty in security studies is no loyalty, as an order in the military is scalar; hence the saying 'obey the last order', because allegiance is a very important factor in financial studies, security studies and collective bargaining.

Another challenge is the weakness in regional integration and cooperation in the region: The basis for the integration of SADC member states was formalised in 2003 through the Regional Strategic Development Plan (RISDP). The framework, though not a legally binding document, enjoys political legitimacy and is often seen as the architecture for regional integration (Hartzenberg 2008:2). The RISDP provides the roadmap for the establishment of Free Trade Agreements by 2008, Southern African Custom Union in 2010, Common Market in 2015, monetary union by 2016 (which did not work) and a single currency by 2018 (Hartzenberg 2008:2).

Economic regional integration is capable of unlocking the potential for economic acceleration of the region (Du Pisani, Erasmus \& Hartzenberg 2012:iii). However this has been limited by unsuitable and unsustainable formulas that do not address the challenges confronting regional integration in the region, as a result of shortages in capacity, finance, equipment and resource concerns, overlapping member states of RECs in the region, lack of experts and most importantly the political will to fulfil the lofty agreement (in Windboek Protocol, RISDP, PACT, OPSDC, Strategic Indicative Plan for the Organ), which have consequently reduced the volume of intra-regional trade to a large extent.

The volume of trade in most African markets is small, thereby making transactions more expensive, in addition to the high risk of doing business in the region as a result of uncertainty, low trading, low economic power and deficiencies of benefits from the economies of scale among member states (Njinkeu \& Fosso 2006, quoted in Geda \& Seid 2015:23). 
Regional integration has been identified as the most adequate mechanism towards continental development (Geda \& Seid 2015), but this has been hindered by the fact that:

35 percent of the population and one-third of the economies in the continent are trapped as landlocked countries whose trade and development depend on what happens in their costal neighbors ... most countries in Africa are small in size and hence their economic feasibility and global bargaining position individually are highly limited. (p. 3)

Therefore, making the member states in the region and the continent rely otherwise, depends on the global political economy for favours, coupled with the height of political and all other forms of corruption and human rights abuses in the region.

A compelling factor that cannot be ignored is the weak governance system in the region. The government system of SADC has little potential to influence decisions reached in individual member states; neither does it have the mandate to ensure compliance with its decision on security issues in member states, because most countries in the region are donor driven and because of the sovereignty of member states (Nzewi 2009). This has significantly curtailed the influence the regional body has on its member states, with most of the member states being an appendage in reality to their donors, who determine the policies, projects and programmes to be implemented in these nations (Söderbaum \& Stålgren 2009:1).

One of the major characteristics of the structure of government is the stratification of power and authority. Hence, the need in democracies for three arms of government - the executive, the legislature and the judiciary. The SADCSF is a democratic institution, in which power is not centralised but devolved. More so, in a democratic institution there is room for the other two arms to ratify or adjudicate the decisions of the executive. However, although the SADC has an established executive figure, the legislative and judicial arms of the SADC regional governance framework are missing (AU 2015; International Democracy Watch 2015).

According to Caparini and Marenin (2006:217), the issue of security governance is indeed a very sensitive concept, as stated $a b$ initio in Southern Africa, as it is to the entire continent. The difficulties in determining what security threats are and what security denotes have been problematic in contextualising different member states, which have culminated in greater confusion regarding who determines an act of grave consequence, intervention in member states and preventive measures and deployment for preventive purposes. With no proper governance structures, and the fact that it lacks a judicial arm for the interpretation of these events, little can be achieved, in addition to the nonchalant political will as to what constitutes security governance or reforms and security threats in the region (Hänggi 2003:4-8). It would be difficult to interpret the ambiguous and vague terminology used in the SADC Memoranda of Understanding document of 2007 as an observation and monitoring mission, considering that the observation and monitoring exercise of Zimbabwe's election was a failure at demonstrating what the country holds sacrosanct.

\section{Discussion}

Regional or continental unification or otherwise integration has been argued as a basis for African growth and development. Nkrumah, the father of pan-Africanism, was the first to call for such unification and integration. In his book Africa Unite, Nkrumah admonished the continent to unite or perish (New African Magazine 2013; Ojukwu 2013). The concept of African unity is based on the assumption that regional integration and cooperation is the only means through which Africa can bridge the gap between the South and the North. This is one of the major aims for the establishment of New Partnership for Africa's Development by the AU, namely 'to promote regional economic integration by bridging Africa's Infrastructural gap (AU 2015)' with the West.

One of the founding members of the AU, Thabo Mbeki, was of the view that there would be no meaningful development in the continent except where the continent are fully integrated, likewise in SADC except where member states are truly integrated, the region will not prospers and where the region does not prosper the prosperity of the continent will suffer an imbalance and vice versa (Ndaguba 2016). This was the same notion shared by Nkrumah during the independence speech of Ghana, that Ghana would not be independent until the independence of the entire continent (Ndaguba et al. 2018). Hence, unless the regions are properly harmonised in terms of regional economic trade unification (Ndaguba \& Okonkwo 2017), the aim of Africa's development cannot be guaranteed and peace will remain elusive or perhaps a ghost case.

In the SADCU (n.d.) context, the AU vision is engendered through a:

common future, a future ... that will ensure economic wellbeing, improvement of the standards of living and quality of life, freedom and social justice and peace and security for the peoples of Southern Africa ... anchored on the common values and principles and the historical and cultural affinities that exist between the peoples of Southern Africa. (p.21)

From the SADC perspective, there are three major areas where regional integration may result in the actualisation of the visions of the AU in line with regional integration and also in line with the visions of the Strategic Indicative Plan for the Organ (SIPO), Regional Indicative Strategic Development Plan (RISPD) and Organ on Politics, Defense and Security Co-operation and the SADC Mutual Defense Pact (OPDSC and MDP) in the region. These three major aspects are trade and investment, economics or political economy, and security. For the intents of this subject area, these three are perils to peace, stability, development and security in the SADC in particular and Africa in general. Therefore, it is a truism that trade breeds innovation, which tends to create employment, housing and empowerment that 
reduces dependency and poverty in a nation, region or continent, based on the improvement of science and technology, which in turn increases foreign direct investment. The political economy of regionalism establishes a direct organisation of administration, leading to the following: a balance of payment, increased labour, prudent use of land, political will, increased transactions and strengthened regional governance and capability, including security (Ndaguba 2016).

The nexus between security and development has long been established (Chandler 2007; Stern \& Öjendal 2010; Uvin 2002), in that conflict, wars, terrorism and disharmony threaten investors' confidence to inject funds into an uncertain economy. Examples can be drawn from the 2015 xenophobic incident in South Africa, the long period of war that resulted in a downward economic movement in the Congo and the Boko Haram terror group in Northeast Nigeria that challenges the infusion of legitimate investors. Therefore, without peace and security no economy can grow nor claim to develop (see Syria, Afghanistan, Congo).

According to Bösl, regional integration as carried out by RECs is the most important and successful instrument of economic growth, political cooperation, socioeconomic development and general stability in the region (SADC nd:25). The globalisation process has beclouded the region with more threats than opportunities (Ouattara 1997). Therefore, the region must adopt models and policy direction in terms of accommodating immigrants, employment opportunities for all, inclusive security and so forth. To avoid such threats, the region must be prepared to accommodate massive immigration, embrace technological advancement and prepare for chemical weaponry and diseases to ensure the security of the region. In addition to economic growth and viability, regional integration can perhaps also play a compelling role in pursuing and resolving matters of common concern through the RECs.

In this sense, regional integration and strong RECs in general may pay substantial dividends in the region, especially in the context of identifying and resolving common challenges that are beyond the borders of individual states (Chingono \& Nakana 2009; Ginkel et al. 2003; Ndaguba \& Okonkwo 2017). This may include but is not limited to transnational crimination, piracy, human rights abuses and diverse threats to peace in the region: terror groups, insurgency, xenophobia and a host of others (Ndaguba et al. 2018). It can be argued that global and regional challenges ravaging the region constitutes reasons for collective action to prevail over individualistic actions in order to stimulate regional cooperation, which predominantly leads to strengthening its organs. Hence there is little or no chance of any individual member states making a significant impact in the global arena. Nevertheless, the nature of commodity, wealth, capital and resources has been the major pitfall of the regional integration agenda of the SADC member states

\section{Conclusion}

From the foregoing, it is evident that much still needs to be achieved for the SADCSF to possibly be operational - thus, the identification of several indicators. The analyses from the article portray that while much has been achieved, much more is yet to be realised in terms of fiscal viability, sustainability, responsibility and integration. However, continuous adjustment, pedalling and movement are essential towards greater unification and integration in the region.

The article suggests that by creating vibrant institutions and structures that determine the interaction of events and activities in the region in particular and the continent in general, there is hope for sustainable peace and the effective funding for peace operation of the SADCSF.

In conclusion, though it seemed impossible for the SADCSF to become fully operational and carry out its basic responsibility of peace operations, premised on the identified pull-down factors, it is the view of this article that creating a partnership-funding model is the first step towards realising an achievable and functional SADCSF. In order for a model to be proposed from the analysis in the article, factors that are geared towards financial viability should be used for such a venture. Therefore, it is important to take lessons from other regional security arrangements and the principal security agency on how it managed to fund peacekeeping or peace missions over the years, including the funding mechanisms used in financing their operations, as well.

\section{Acknowledgements Competing interests}

The author declares that the has no financial or personal relationships which may have inappropriately influenced him in writing this article.

\section{References}

Allison, S., 2013, Standing by to standby: The African peacekeeping force with more problems than solutions, Daily Maverick, viewed 14 August 2012, from http:// www.dailymaverick.co.za/article/2012-08-14-standing-by-to-standby-theafrican-peacekeeping-force-with-more-problems-than-solutions\#.VXx032bpiai

Allison, S., 2015, 'Will South Africa really go to war in the DRC again?', Daily Maverick, viewed 21 March 2016, from www.dailymaverick.co.za/article/2015-01-05-willsouth-africa-really-go-to-war-in-the-drc-again/\#.Vbp-e0Xpiai

Ansoff, I., 1965, Corporate strategy, McGraw-Hill, New York.

$\mathrm{AU}, 2015$, The Executive Council, African Union, viewed 07 December 2015, from www.au.int/en/organs/council

Bezuidenhout, $H_{\text {., }}$ 2016, SADC investment perspectives in a changing internationa investment landscape, Policy Insights 12, Economic Diplomacy, SAllA, Durban, South Africa.

Burrowes, R.J., 1996, The strategy of nonviolent defense: A Gandhian approach, SUNY Press, NY.

Buti, M. \& Carnot, N., 2015, What is a 'responsible' fiscal policy today for Europe? CEPR's Policy Portal, VOX, viewed 26 September 2015, from http://www.voxeu. org/article/defining-responsible-fiscal-policy-europe

Buzan, B. \& Wæver, O., 2013, Regions and powers: The structure of international security, Cambridge University Press, Cambridge.

Campion, M. \& Thayer, P., 1987, 'Job design: Approaches, outcomes, and trade-offs', Organizational Dynamics 15(3), 66-79. https://doi.org/10.1016/0090-2616(87) 90039-8 
Cantori, L.J. \& Spiegel, S.L., 1970, The international politics of regions, Englewood Cliffs, N.J., Prentice-Hall.

Caparini, M. \& Marenin, O., 2006, Borders and security governance: Managing borders in a globalised World, Die Deutshe Bibliothek, Deutsche.

Chandler, A.D., 1962, Strategy and structure: Chapters in the history of the American Industrial Enterprise, MIT Press, Cambridge, MA.

Chandler, D. 2007. The security-development nexus and the rise of 'anti-foreign policy', Journal of International Relations and Development, 10(4):362-386

Chandler, A.D., 2013, Strategy and structure: Chapters in the history of the Industrial Enterprise, MIT Press, MA. (Reprint)

Chellah, C., 2014, Joint media release on the handling over of accommodation to SADC Regional Peacekeeping Trading Centre by the government of the Federal Republic of Germany, SACD, viewed 14 June 2018, from https://www.sadc.int/ files/7713/9505/2070/HANDING OVER OF ACCOMMODATION TO SADC REGIONAL PEACEKEEPING TRAINING CENTRE_2.pdf

Chingono, M. \& Nakana, S., 2009, 'The challenges of regional integration in Southern Africa', African Journal of Political Science and International Relations 3(10), 396-408.

Cilliers, J., 2008, The African standby force: An update on progress (ISS Paper No 160), ISS, Pretoria.

Cimbala, S., 2001, Through a glass darkly: Looking at conflict prevention, management and termination, Praeger, Westport, Ct.: Praeger Publishers, 2001.

Eising, R. (eds.), 2005, 'Reshuffling power: The liberation of the EU electricity markets and its impact on the German governance region', in B. Kohler-Koch \& R. Eising

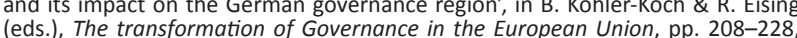
(eds.), The transformatic
Routledge, New York.

Fawcett, L. \& Gandois, H., 2010, 'Regionalism in Africa and the Middle East: Implications for EU studies', Journal of European Integration 32 (6), 617-636. doi: 10.1080/07036337.2010.51871921

Francis, D.J., 2012, 'Peace, security and developmental regionalism: Regional economic and security integration in Africa', Journal of Peacebuilding \& Development 2(3), 2006.

Furrer, O., Thomas, H. \& Goussevskaia, A., 2008, 'The structure and evolution of the strategic management field: A content analysis of 26 years of strategic management research', Blackwell Publishing Ltd., International Journal of Management Reviews 10(1), 1-23. https://doi.org/10.1111/j.1468-2370.2007. 00217.x

Gaddis, J.L., 1982, Strategies of containment: A critical appraisal of Postwar American National Security policy, Oxford University Press, New York.

Gane, M., 2007, Forest strategy: Strategic management and sustainable development for the forest sector, Springer, Dordrecht, The Netherlands.

Geda, A. \& Seid, E.H., 2015, 'The potential for internal trade and regional integration in Africa', Journal of African Trade 2(1-2), 19-50. https://doi.org/10.1016/j. joat.2015.04.001

Gibb, R., 2009, 'Regional integration and Africa's development trajectory: Metatheories, expectations and reality', Drake Circus, Plymouth: Third World Quarterly 30(4), 701-721. https://doi.org/10.1080/01436590902867136

Ginkel, H.V., Court, J. \& Van Langenhove, L., 2003, Integration Africa: Perspective on Regional Integration and Development, United Nations University CRIS, United Nations University Press.

Hänggi, H., 2003, 'Making sense of security sector governance', in H. Hänggi \& T.H. Winkler (eds.), Challenges of security sector governance, pp. 1-22, LIT Verlag, Munster.

Hartzenberg, T., 2008, Comments on the SADC Free Trade Area to be launched at SADC Summit viewed 14 June 2018, from www.thedti.gov.za/parliamentary/regionaltra deissues.pdf

Hettne, B. \& Söderbaum, F, 2000 'Theorising the rise of regionness', New Political Economy 5, 457-472. https://doi.org/10.1080/713687778

Hettne, B. \& Söderbaum, F., 2006, The UN and Regional Organizations in Global Security: Competing or Complementary Logics? Global Governance: A Review of Multilateralism and International Organizations, 12(3) 227-232.

Hofer, C.W. \& Schendel, D., 1978, Strategy formulation: Analytical concepts, West Group, New Mexico.

Homan, K., 2006, NATO, Common funding and peace support operations: A comparative perspective, Road to transformation summit, $1 \mathrm{st} A B C / D$, In Road to Transformation Summit, Baltic Defence College, Tartu, Estonia, 1-2 June, 2006.

International Democracy Watch, 2015, International Democracy Watch, African Union, viewed 07 December 2015, from www.internationaldemocracywatch.org/ index.php/african-union

Jentzsch, C., 2014, The financing of international peace operations in Africa: A review of recent research and analyses, APN Working Papers No. 1, Social Science Research Council, African Peacebuilding Network, South Africa, Cape Town.

Jervis, R., 1997, System Effects: Complexity in Political and Social Life, Princeton University Press, Princeton.

Jevon, S.W., 1957, The theory of political economy, 5th ed., Kelley \& Millman, New York.

Jordan, A.A., Taylor, J., William, J., Meese, M.J., Nielsen, S.C. \& Schlesinger, J., 2009 American National Security, The Johns Hopkins University Press, Project MUSE, Baltimore, MD.

Learned, E.P., Andrews, K.R., Christensen, C.R. \& Guth, W.D., 1965, Business policy: Text and cases, Irwin, Homewood, IL.
Lee, M., 2002, Regionalism in Africa: A part of problem or a part of solution, AAPS: Polis/R.C.S.P./C.P.S.R., vol. 9, Numéro Spécial, 2002

Lorange, P. \& Vancil, R.F., 1977, Strategic planning systems, Prentice-Hall, Michigan.

Mataboge, M. \& Pillay, V., 2014, 'South African soldiers injured in DRC attack', Mail \& Guardian, 01 May, 2014, viewed 31 October 2015, from http://mg.co.za/ article/2014-05-01-south-african-soldiers-injured-in-drc-attack

Messner, J.J., Haken, N., Taft, P., Blyth, H., Lawrence, K., Pavlou, S. et al., 2015, Fragile states index 2015: The book, ISSUU, Fund for Peace Library, Washington, DC.

Milward, A.S., 1979, 'Strategies for development in agriculture: The nineteenthCentury European experience', in T.C. Smout (ed.), The search for wealth and stability: Essays in economic and social history presented to M. W. Flinn, pp. 2142, Macmillan, London.

NATO Handbook, 2001, NATO/OTAN HANDBOOK, NATO Office of Information and Press, Brussels. ISBN 92-845-0146-6.

Ndaguba, E.A., 2016, Financing regional peace and security in Africa: A critical analysis of the Southern African Development Community Standby Force, UFH Library, 2017 (Master Dissertation).

Ndaguba, E.A. \& Okonkwo, C., 2017, 'Feasibility of funding peace operation in Africa: Understanding the challenges of Southern African development community standby force (SADCSF)', Africa Review 9(2), 140-153. https://doi.org/10.1080/09 standby force (SADCSF
744053.2017.1329807

Ndaguba, E.A., 2018. 'Task on Tank model for funding peace operation in Africa - a Southern African perspective', Cogent Social Sciences 4(1), 1-32. https://doi.org/ 10.1080/23311886.2018.1484414

Ndaguba, E.A., Nzewi, O.I. \& Shai, B.K., 2018, 'Financial imperatives and constraints towards funding SADC standby force', India Quarterly 74(2), 1-19. https://doi. org/10.1177/0974928418766732

New African Magazine, 2013, "We must unite now or perish" - President Kwame Nkrumah. Retrieved May 03, 2013, from, http://newafricanmagazine.com/wemust-unite-now-or-perish/

Njineku, D. \& Fosso, B.P., 2006, 'Intra-African trade and regional integration in Africa', paper prepared for ADB/AERC International Conference on Accelerating Africa's Development Five Year into the 21st Century', Tunis, November 22, 2006.

Ojukwu, H., 2013, Kwame Nkrumah: A true champion of african unity. Retrieved July 1, 2013, from. uhuruspirit.org/opinion/opiniondetail.php? $x=21 \# . V a 5 c l U X p i a$

Okoth, E., 2015, Africa to take four out of 10 slots for fastest growing economies globally, viewed 10 October 2015, from www.nation.co.ke/lifestyle/smart company/Africa-for-fastest-growing-economies-globally/-/1226/2744754/-/ xruv0mz/-/index.html

Ouattara, A.D., 1997, The challenges of globalization for Africa, World Economic Forum, Harare, May 21, 1997.

Rosecrance, R. \& Stein, A.A., 1993, 'Beyond realism: The study of grand strategy', in R. Rosecrance \& A. Stein (eds.), Domestic bases of grand strategy, pp. 3-21, Cornell University Press, Ithaca, NY.

Sabra, Y., 2011, Challenges facing UN peace operations in Africa: The cases of South Sudan and Libya, Challenges Forum Research Adviser, Former Head of Office of the United Nations SRSG in Cyprus, View 14 June 2018, from http://www. challengesforum.org/Global/Forum\%20Documents/2011\%20Sharm $\% 20$ El $\% 20$ Sheikh,\%20Egypt/Background $\% 20$ Papers/Background $\% 2$ Paper $\% 20$ Sabra $\% 20$ Sharm\%20el\%20Sheikh\%20Feb\%202012.pdf

SADC, 2015a, SADC facts \& figures, viewed 06 November 2015, from www.sadc.int/ about-sadc/overview/sadc-facts-figures/\#GDP

Söderbaum, F. \& Stålgren, P., 2009, The European Union and the Global South, Lynne Rienner Publishers, Boulder, CO. Steiner, G.A. \& Miner, J.B., 1977, Management policy and strategy, Macmillan, New York.

Söderbaum, F. \& Van Langenhove, L., 2005, Introduction: The EU as a Global Actor and the Role of Interregionalism, European Integration, 27:3, 249-262. DOI: 10.1080/07036330500190073

Steiss, A.W., 2003. Strategic Management for Public and Nonprofit Organizations, Routledge, NYC. (Public Administration and Public Policy).

Stern, M. \& Öjendal, J., 2010, 'Mapping the security-development nexus: Conflict, complexity, cacophony, convergence?', Security Dialogue 41(1), 5-29. https://doi. org/10.1177/0967010609357041

ToddZenger, N., 2015, 'New ways to compete: Build a theory, then a strategy', Hard Business Review, viewed 08 May 2015, from https://hbr.org/2015/05/new-waysto-compete-build-a-theory-then-a-strategy

Trager, F.N. \& Simonie, F.L., 1973, 'An introduction to the study of National Security', in F.N. Trager \& P.S. Kronenberg (eds.), National security and American society Theory, process, and policy, pp. 1-37, National Security Education Program by the University Press of Kansas, Michigan.

Uvin, P. 2012. The Development/Peacebuilding Nexus: A Typology and History of Changing Paradigms, Journal of Peacebuilding \& Development, 1(1):5-24. https:// doi.org/10.1080/15423166.2002.979203266676

Weihrich, H., 1982, 'The TOWS matrix: A Tool for Situational Analysis', Long Range Planning, 15(2):54-66.

Yarger, H.R., 2006, Strategic theory of for the 21st century: The little book on big strategy, Strategic Studies Institute, Carlisle, PA.

Yarger, H.R., 2008, Strategy and the national security professional: Strategic thinking and strategy formulation in the 21st Century, Praeger PA. 